\title{
Pembuatan Peta Foto Udara Kelurahan Wates
}

\author{
Waljiyanto $^{1}$, Rochmad Muryamto ${ }^{2}$, M. Iqbal Taftazani ${ }^{* *}$, Ruli Andaru ${ }^{4}$, Untung \\ Rahardjo $^{5}$, Gondang Riyadi ${ }^{6}$, Wahyu Marta $\mathrm{M}^{7}$., Annisa Farida H. ${ }^{8}$, Anindya Sricandra \\ P.9, Ni Putu Praja C. ${ }^{10}$
}
1,2,3,4,5,6,7,8,9,10 Program Studi Teknik Geomatika, Departemen Teknologi Kebumian Sekolah Vokasi, Universitas Gadjah Mada

*iqbaltaftazani@ugm.ac.id

\begin{abstract}
ABSTRAK
Kelurahan Wates merupakan pusat pemerintahan di Kabupaten Kulon Progo, sehingga secara tidak langsung aktivitas kelurahan berpengaruh terhadap kelangsungan Pemerintahan Kabupaten Kulon Progo. Keterbatasan anggaran menyebabkan beberapa aspek dasar dalam hal data geospasial tidak muncul di dalam Renja 2017. Sebagai contoh belum adanya rencana kegiatan dalam hal pemetaan desa/kelurahan. Hal tersebut dapat menjadi peluang bagi perguruan tinggi untuk melaksanakan kegiatan penelitian dan pengabdian kepada masyarakat, khususnya dalam penyediaan data geospasial. Berdasarkan pokok permasalahan tidak tersedianya data geospasial, dapat diberikan solusi dengan pengadaan salah satu bentuk data geospasial, yaitu Peta foto udara. Peta foto udara Kelurahan Wates disajikan dalam skala besar yaitu antara 1:1000 - 1:5000. Dari peta foto yang akan dihasilkan ini, nantinya dapat dikembangkan untuk membuat peta-peta turunan lainnya, seperti peta sarana-prasarana, peta jaringan jalan, dan sistem informasi desa yang direncanakan akan dibuat dalam pengabdian masyarakat pada tahun-tahun berikutnya.
\end{abstract}

Kata Kunci: foto udara, geospasial, peta foto, Wates

\section{ABSTRACT}

Wates Subdistrict is the center of Kulon Progo Regency government, indirectly for the kelurahan that is related to Kulon Progo Regency Government due to limited budgets, some things in the geospatial data will not appear in Renja 2017. For example, there are no planned activities regarding village / kelurahan mapping. Thus, this can be an opportunity for universities to carry out research and community service activities, especially in the availability of geospatial data. From the presentation of the problem, the main thing is the absence of geospatial data, and it can be provided with one form of geospatial data, namely the large-scale Wates Urban Air Photo Map, which is between 1: 1000-1: 5000. The output from this service, in the form of Large-scale Wates Urban Air Photo Map. From the maps that will be produced, it can be developed to make other derivative maps, such as facilities and infrastructure maps, road network maps, and village information systems that will be created in community service in the following years..

Keywords: aerial map, aerial photograph, Geospatial, Wates,

\section{PENDAHULUAN}

Kelurahan Wates merupakan sebuah kelurahan yang berada di Kecamatan Wates, Kabupaten Kulon Progo. Pada awal bedirinya Kelurahan Wates ini berbentuk desa, dimana seluruh asset menjadi milik desa dan digunakan seluasnya untuk kemakmuran dan kesejahteraan warga Desa 
Wates. Pada tanggal 1 Desember 2010 status Desa Wates berubah menjadi Kelurahan Wates dengan dasar hukum Peraturan Daerah Kabupaten Kulon Progo Nomor 16 Tahun 2008 tentang Perubahan Status Desa Wates Menjadi Kelurahan Wates, sebagaimana telah diubah dengan Peraturan Daerah Kabupaten Kulon Progo Nomor 9 Tahun 2009 tentang Perubahan Atas Peraturan Daerah Kabupaten Kulon Progo Nomor 16 Tahun 2008 tentang Perubahan Status Desa Wates Menjadi Kelurahan Wates (www.kelurahanwates.kulonprogokab.go.id)
Kelurahan Wates memiliki banyak keistimewaan. Sebagaimana namanya, Wates yang berarti batas dalam Bahasa Indonesia, Kelurahan Wates juga merupakan kelurahan perbatasan dari Kecamatan Wates. Adapun batas-batasnya di sebelah barat dan utara adalah Kecamatan Pengasih, sedangkan di sebelah timur dan selatan merupakan desa-desa di dalam Kecamatan Wates, yaitu Desa Giripeni dan Desa Triharjo di sebelah timur, dan Desa Giripeni di sebelah timur. Adapun peta Kelurahan Wates disajikan pada Gambar 1 berikut.

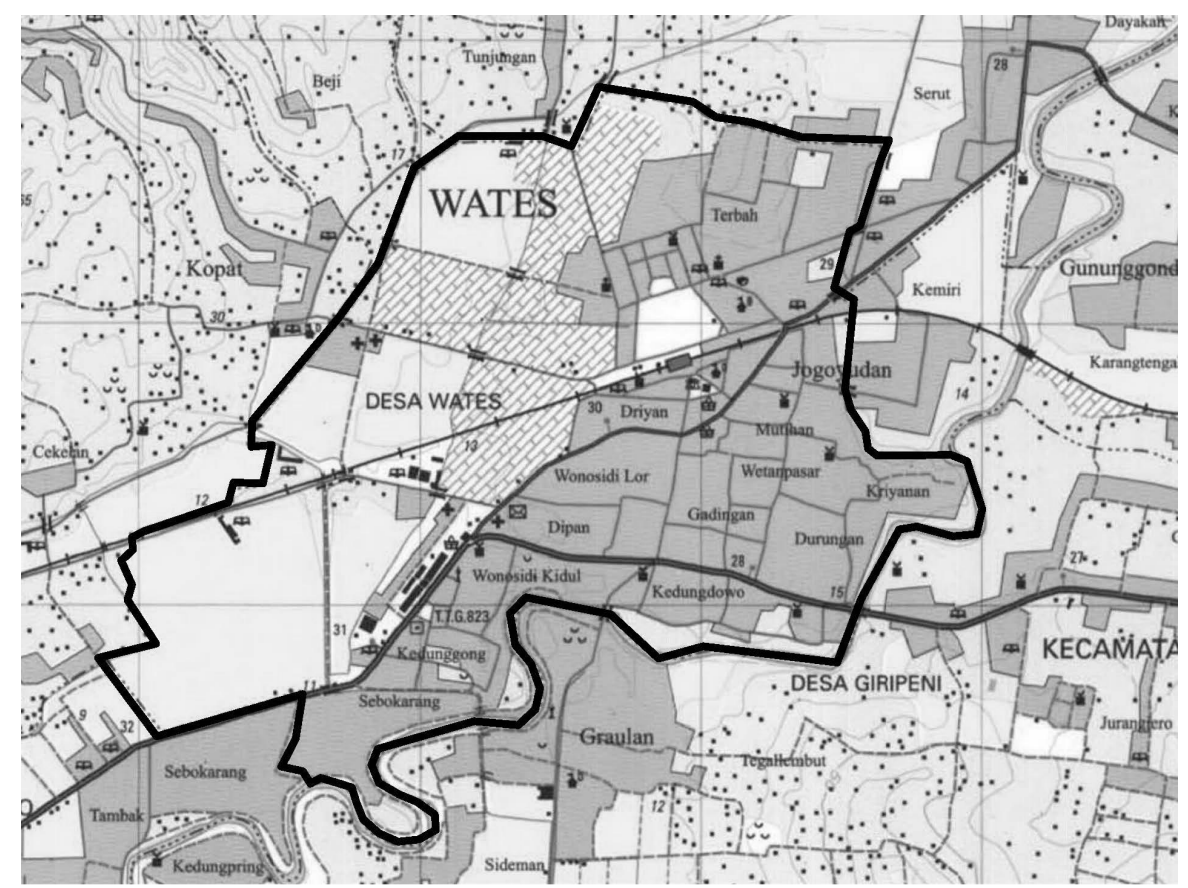

Gambar 1. Peta Kelurahan Wates (sumber Peta RBI Wates, 1999)

Kelurahan Wates merupakan pusat pemerintahan Kabupaten Kulon Progo, sehingga secara tidak langsung aktivitas kelurahan berpengaruh terhadap kelangsungan Pemerintahan Kabupaten Kulon Progo. Dalam LKjIP Kelurahan Wates tahun 2016 serta Renja 2017 disebutkan bahwa Kelurahan Wates mengalami kendala dalam sarana prasarana, baik di dalam lingkungan kantor kelurahan sendiri ataupun berkenaan dengan lingkungan kelurahan. Hal ini disebutkan di dalam LKjIP dan Renja disebabkan karena tidak maksimalnya dana yang didapatkan karena merupakan alokasi penganggaran Kecamatan dan Pemerintah Kabupaten. Berbeda dengan desa di sekitarnya yang mendapatkan Dana Desa dan Alokasi Dana Desa karena statusnya masih desa. Selain itu, karena terbatasnya anggaran, beberapa aspek dasar dalam hal data geospasial juga tidak muncul di dalam Renja 2017. Sebagai contoh belum adanya rencana kegiatan dalam hal pemetaan desa/kelurahan. Sehingga hal ini bisa menjadi peluang bagi perguruan tinggi untuk melaksanakan kegiatan penelitian dan pengabdian kepada 
masyarakat, khususnya dalam penyediaan data geospasial.

Salah satu kendala yang dialami kelurahan Wates, sesuai dengan LKjIP 2016 dan Renja 2017 adalah minimnya dana sehingga aspek mendasar dalam hal data geospasial tidak masuk dalam rencana kerja. Padahal keberadaan data geospasial merupakan hal yang penting dalam rangka perencanaan sebuah kawasan, dalam hal ini adalah Kelurahan Wates. Dengan adanya data geospasial dapat dilakukan perencanaan dan analisis kewilayahan menggunakan peta dengan data terbaru, sehingga dapat mendukung keberlangsungan dan keberlanjutan visi Kelurahan Wates yaitu "Terwujudnya Penyelenggaraan Pelayanan Pemerintahan yang Prima."

\section{METODE}

Kegiatan pengabdian ini dilaksanakan dalam beberapa tahapan. Tahap awal adalah dengan melakukan penjajagan kepada Pemerintah Kelurahan Wates dalam hal ini penjelasan mengenai pentingnya data geospasial dalam mendukung perencanaan desa/kelurahan. Adapun tahapan berikutnya tentang proses pembuatan peta foto seperti disajikan dalam diagram alir berikut.

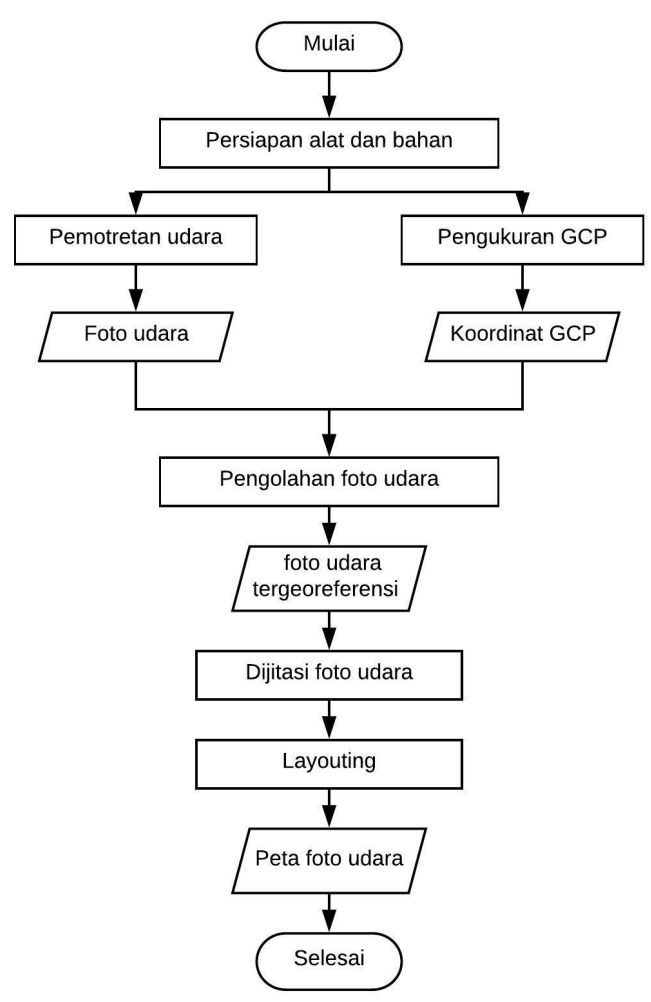

Gambar 2. Diagram alir pelaksanaan

Penjelasan tahapan dari diagram alir di atas:

Penjajagan dan penjelasan tentang pentingnya data geospasial dalam perencanaan desa/kelurahan

Persiapan alat dan bahan, dalam tahapan ini menyiapkan alat dan bahan yang diperlukan selama penelitian, khususnya penyiapan dalam proses pemotretan udara dan pengukuran GCP

Pemotretan udara, dilakukan dengan menggunakan wahana UAV memotret kawasan Kelurahan Wates

- Pengukuran GCP, dilakukan dengan menggunakan receiver GPS geodetik untuk mendapatkan koordinat yang nantinya akan digunakan untuk pengolahan foto udara.

- Pengolahan foto udara, dilakukan dengan menggunakan perangkat lunak pengolahan foto udara dan bahan berupa foto udara hasil pemotretan dan titik koordinat GCP. Hasilnya berupa foto udara tergeoreferensi.

- Foto udara tergeoreferensi selanjutnya dilakukan digitasi bidang-bidang dan bangunan yang ada di dalam foto tersebut

Selanjutnya dilakukan konsultasi kepada aparat kelurahan dan/atau masyarakat untuk 
meminta masukan terkait peta yang dibuat.

8. Serah terima peta foto, jika peta foto telah selesai dibuat.

Adapun alatn dan bahan yang digunakan dalam pengabdian masyarakat ini sebagai berikut :

1. UAV untuk akuisisi data spasial

2. Receiver GPS/GNSS untuk akuisisi data GCP

3. Komputer untuk pengolahan data foto, data
GPS, dan pembuatan geodatabase

Printer untuk pencetakan laporan

\section{HASIL DAN PEMBAHASAN}

Hasil dari pelaksanaan pengabdian masyarakan ini berupa peta foto udara yang meliputi seluruh kawasan Kelurahan Wates. Adapun peta foto hasil pemotretan disajikan pada Gambar 3 di bawah.

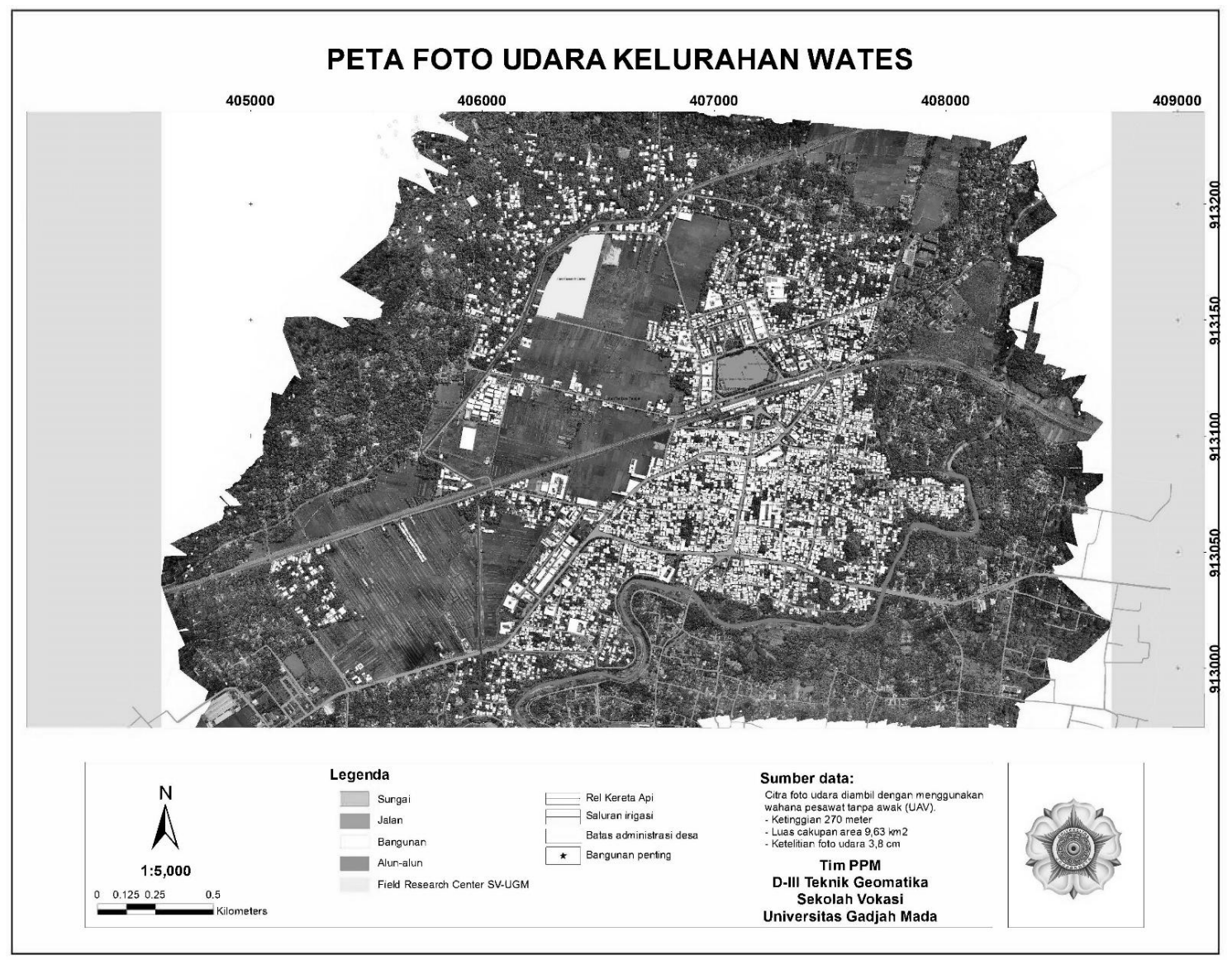

Gambar 3. Peta Foto Udara

Gambar 3 di atas menunjukkan Peta Foto Udara Kelurahan Wates hasil dari pemotrtan udara menggunakan pesawat tanpa awak jenis fixed wing. Hasil peta foto di atas merupakan hasil akhir dari kegiatan pengabdian masyarakat ini.

Peta foto merupakan salah satu jenis dari bermacam-macam jenis peta. Secara umum peta dibuat untuk memenuhi fungsi tertentu. Menurut International Cartograph Association, fungsi peta antara lain adalah untuk menunjukkan posisi atau lokasi relatif yang hubungannya dengan lokasi asli di permukaan bumi, mampu memperlihatkan ukuran, mampu menyajikan dan memperlihatkan bentuk, mengumpulkan dan menyeleksi data dari suatu daerah dan menyajikan diatas peta dengan simbolisasi. Adapun tujuan pembuatan peta antara lain untuk komunikasi ruang, media menyimpan informasi, membantu pekerjaan, membantu dalam desain, dan analisis data spasial.

Dengan fungsi dan tujuan tersebut, diharapkan peta foto dari hasil pengabdian 
masyarakat ini dapat berdayaguna untuk pemerintah Kelurahan Wates, terutama dalam perencanaan kawasan Kelurahan Wates.

\section{SIMPULAN}

Dari pemaparan di atas, dapat disimpulkan bahwa kegiatan pengabdian masayarakat telah menghasilkan produk berupa Peta Foto Kelurahan Wates. Peta foto ini diharapkan dapat digunakan tidak hanya sebagai penunjuk lokasi saja, tetapi diharapkan dapat didayagunakan untuk kegiatan perencanaan kawasan Kelurahan Wates.

Adapun saran yang dapat diberikan adalah agar peta foto yang sudah ada dapat dikembangkan dengan penambahan informasi-informasi atributif yang ada di Kelurahan Wates yang bereferensi lokasi. Sehingga dapat meningkatkan fungsi peta foto tersebut dan dapat membantu dalam perencanaan kawasan dan penyelesaian masalah terutama yang berkenaan dengan referensi lokasi.

\section{DAFTAR PUSTAKA}

--, 2018, Profil Kelurahan Wates, dalam www.kelurahanwates.kulonprogoka b.go.id, akses tanggal 10 Maret 2018.

Bakosurtanal, 1999, Peta RBI Digital 1:25.000 Lembar 1408-214 Wates, Badan Koordinasi Survei dan Pemetaan Nasional, Cibinong, Bogor Kelurahan Wates, 2016, Laporan Kinerja Instansi Pemerintah Tahun 2016 (LKjIP), Kelurahan Wates, Kulon Pprogo

Kelurahan Wates, 2016, Rencana Kerja Tahun 2017, Kelurahan Wates, Kabupaten Kulon Progo 